\author{
POLITYKA ENERGETYCZNA - ENERGY POLICY JOURNAL \\ $2021 \downarrow$ Volume $24 \uparrow$ Issue $3 \uparrow 61-78$ \\ DOI: $10.33223 /$ epj/141990
}

\author{
Viktor Koval $^{1}$, Yevheniia Sribna ${ }^{2}$, Sylwester KaCZMarzewski $^{3}$, Alla Shapovalova ${ }^{4}$, \\ Viktor STUPNYTSKYI ${ }^{5}$
}

\title{
Regulatory policy of renewable energy sources in the European national economies
}

ABSTRACT: The article analyzes and evaluates the development of renewable energy from the standpoint of state regulation and incentives. It is noted that the global production of renewable electricity has increased by $15 \%$ over the last year. The periods of introduction of the "green tariff" as an economic stimulus for the development of solar energy, which became the starting point for the development of alternative generation in different countries, are analyzed. The role of institutional factors in the development of renewable energy, such as the free issuance of licenses for electricity generation, stimulating the creation of specialized research areas, technology development and production of relevant equipment, was observed. The necessity of taking into account the regional peculiarity in the state stimulation of the development of renewable energy is proved. The economic efficiency

$\triangle$ Corresponding Author: Viktor Koval; e-mail: victor-koval@ukr.net

1 National Academy of Sciences of Ukraine, Ukraine; ORCID iD: 0000-0003-2562-4373; e-mail: victor-koval@, ukr.net

2 National University of Water and Environmental Engineering, Ukraine; ORCID iD: 0000-0002-6676-0606; e-mail: e.v.sribna@nuwm.edu.ua

3 Mineral and Energy Economy Research Institute Polish Akademy of Sciences, Kraków, Poland; ORCID iD: 00000002-6076-9626; e-mail: skaczmarzewski@meeri.pl

4 V.I. Vernadsky Taurida National University, Ukraine; ORCID iD: 0000-0002-4920-5539; e-mail: a_shan65@ukr.net

5 Dubno Branch Higher Education Institution «Open International University of Human Development «Ukraine», Ukraine; ORCID iD: 0000-0001-8845-7643; e-mail: rantver@gmail.com

2021. The Author(s). This is an open-access article distributed under the terms of the Creative Commons Attribution-ShareAlike International License (CC BY-SA 4.0, http://creativecommons.org/licenses/by-sa/4.0/), which permits use, distribution, and reproduction in any medium, provided that the Article is properly cited. 
of the state regulation of alternative energy in time measurement per conditional unit of alternative renewable energy stations was calculated, taking the coefficient of proportionality into account. Therefore, the calculation indicates the high effectiveness of government policy in regulating energy in terms of only short-term lag $(\alpha=1.3)$ and the number of stations 80 percent of full saturation relative to the basic needs of energy consumption. A separate further stage in the development of renewable energy without the introduction and expansion of the "green tariff" has been identified. This approach was introduced in Poland, which ensured the country not only the inflow of foreign investment, but also the formation of free competition among investors.

Keywords: renewable energy, „green” tariff, preferential taxation, state regulation of renewable energy, solar power plants

\section{Introduction}

The development of renewable energy has become a common economic and social phenomenon in any country. If a decade ago research on this energy focused on the conditions of its stimulation to industrial development, now the priority is to reduce economic incentives and transfer it to the plane of an independent subsector of energy with reduced public funding.

Some developed countries (primarily Germany and Japan) celebrate the development of renewable energy as an integral part of their industrial policy. Therefore, forecasts in these countries for 2050 reflect an increase in the share of alternative sources, including thermal energy to $20.5 \%$, whereas solar electricity to $9.8 \%$ (REN21 2018).

Such development of renewable energy requires a detailed study of the system of its state regulation and stimulation. Simply copying incentives and approaches for an individual country is no longer enough. The experience of one country cannot provide the same effectiveness in another country with automatic implementation. This is not surprising - there is an advantage of the principle of peculiarities of a particular national economy on a general principle (Kholiavko et al. 2020; Yankovyi et al. 2021).

At the same time, this system of state regulation is unique for an individual country (Koval et al. 2021). And this is not surprising, because each country is characterized by a set of characteristics that depend on geographical and climatic factors and socio-economic development of the country. However, the only predominant economic trend in the system of state regulation is the introduction of a change in the so-called "green" tariff.

The priority of tariff regulation of alternative energy, which actually started the era of intensive development of renewable energy, has exhausted its potential. This is clearly seen in countries where this energy has been taken seriously and prudently, and the government has not openly lobbied business interests over public ones. Thus, government regulation plays a key role in the further development of alternative energy. In the scientific approach, the problems of state regulation of alternative energy require in-depth study and explanation. 


\section{Materials and methods}

Renewable energy research assesses changes and trends in alternative energy by country and over time. Such a comparison as a research method made it possible to establish similarities and differences in approaches to the state regulation of alternative energy development. The applied method of abstraction allowed us to trace the trend in the regulation of renewable generation, which began to determine the nature of its current development, namely the departure from the prevailing trend of "green tariff". The application of the system method allowed the assessment of renewable energy in the regional context to be carried out (Bazaluk et al. 2021a; Bazaluk et al. 2021b).

The grouping method allowed countries that have introduced a more uniform policy to stimulate the development of national alternative energy to be identified.

For a reasonable determination of future processes of development of alternative energy due to state regulation, modeling using a mathematical equation with variables is used. This, in turn, ensured the use of graphical analysis using the logistics function. In fact, the economic - mathematical model of the influence of the state regulation system on the development of alternative energy is involved.

The study used a deductive method, which allowed conclusions about the next stage of activation of the development of renewable generation to be drawn. The method of studying normative documents on the researched problem is also used. The study was conducted through analysis and synthesis as a logical method of understanding the phenomenon of the rapid development of renewable generation.

In general, the study applied the rule of argumentation, which allowed logical judgments to deduce the sequence and regularity of the expansion of approaches used in state regulation of the activation of alternative energy. The study is theoretical in nature, which allowed the mathematical and economic regularity of the effectiveness of state regulation of alternative energy to be dervied.

\section{Results and discussion}

\subsection{Features of state regulation of renewable energy in Germany}

The commercial basis of solar energy was based on the development of the process of industrial production of silicon and the production of solar cells by Siemens and becoming Germany's leader in the development of solar energy, despite the fact that solar radiation is not more intense than other southern European countries. In fact, a research and production cluster was 
created, which provided technical popularization of the use of solar energy. Further impetus for the development of renewable energy was provided by the formation of the legislative framework "On the Supply of Electricity from Renewable Energy Sources" (1991) (Bundesministerium für Wirtschaft und Technologie (BMWi 2010)).

According to this law, the obligatory connection of solar stations to the grid was introduced and a reward ("green" tariff) was guaranteed for the electricity produced by these stations for 20 years. In 2000, a new law "On Renewable Energy Sources" (EEG) was adopted and the federal program "10 thousand roofs" was launched (Erneuerbare-Energien-Gesetz 2000). This ensured the annual commissioning of hundreds of megawatts of solar installations and their connection to the grid. In addition, this law has already diversified the payment of the "green" tariff by region (larger payments were received by producers with less intensive solar filling).

The tariff was tied to the total capacity produced (more power and output provided a lower tariff) and the technologies involved. The "green" tariff was defined in absolute terms. It was this German law that formed the basis of the legislation of other countries that began to develop "green energy", and for Germany, these legislative initiatives allowed for a rapid increase in renewable energy. During 2004-2014, the legal framework of German alternative energy was constantly adjusted under the influence of the general economic situation and national priorities (Erneuerbare-Energien-Gesetz 2004). Among these legislative amendments should be noted the increase in the "green" tariff for solar stations; for the first time target indicators were introduced (became an effective stimulus for the development of RES). In 2009, the tariff was reduced, but such a reduction did not reduce the development of solar energy. In 2014, legislative changes marked the regulation of the introduction of new volumes with a limit network of $2.5 \mathrm{GW}$ (Erneuerbare-Energien-Gesetz 2014).

At the same time, payments of the "green" tariff were adjusted in accordance with the introduced capacities, but in general there was a decrease in these payments, and solar stations with a capacity above the limit did not receive payments under the "green" tariff at all. Such requirements for solar energy immediately affected its growth rate. Since 2015, Germany has been losing its leadership in the development of solar energy in the world.

Thus, the experience of legislative regulation in Germany has shown that solar energy has developed through the government's stimulation of institutional factors. The free issuance of licenses for electricity generation is among the tools that have become effective. Economic incentives include soft loans, the introduction of a "green tariff" and grant funding; from an organizational point of view, this is implementation and observance of agreements on the purchase of solar electric power. Such a balanced and consistent policy of the German government has created a situation where half of solar generation belongs to households and farmers, and the other half to generating companies. 


\subsection{Specifics of state regulation of renewable energy in Italy}

Incentive policies differed for energy companies. The government provided soft loans for the implementation of stations in Eastern Europe, where solar activity is highest, as well as government compensation, which fully covered basic research and development. This allowed the formation of a powerful center "Solar Valley" in 2000 (Edie Newsroom 1999). At the same time, the global trend of relocating production bases to the countries of East Asia could not stop the activity of this cluster. SchottSolar, SolarWorld remained in it and continued to work despite the fact that some of them went bankrupt (Q-cells).

A large-scale government program to stimulate the production of solar power plants in 2010 brought Italy to fourth place in the ranking of countries in the world in the number of solar power plants (ahead of the United States at the time) (IRENA 2020). In 2005, a "green" tariff was introduced, which focused exclusively on solar stations with support for 20 years (GSE 2021). And over the next eight years (until 2013), the government introduced various support schemes under the "green" tariff.

TABLE 1. State regulation of tariff policy for renewable energy in Italy

TABELA 1. Państwowe regulacje polityki taryfowej dla energii odnawialnej we Włoszech

\begin{tabular}{|l|l|l|}
\hline \multicolumn{1}{|c|}{ Year } & \multicolumn{1}{|c|}{ Tariff } & \multicolumn{1}{c|}{ Characteristic } \\
\hline 2005 & $\begin{array}{l}\text { Basic "green" tariff } \\
\text { (tariffa onnicomprensiva). } \\
\text { The tariff rate from 0.36 to 0.49 euros/kWh } \\
\text { depends on the combination of the solar instal- } \\
\text { lation to the building elements. }\end{array}$ & $\begin{array}{l}\text { Provided to all facilities with an installed } \\
\text { capacity of 1 kW to 1 MW. From the supply to } \\
\text { the network receive EUR 0.08 - to 0.10/kWh } \\
\text { (depending on the region of the country). }\end{array}$ \\
\hline $\begin{array}{l}\text { Ministerial } \\
\text { decree of July 7, } \\
2012\end{array}$ & $\begin{array}{l}\text { Tariff II (Ritiro dedicato) } \\
\text { (de }\end{array}$ & $\begin{array}{l}\text { Regulation of electricity sales on the market. } \\
\text { Carried out through GSE (state company). If } \\
\text { production exceeds 2,000 MWh, the surplus } \\
\text { fee depends on the market price of electricity. } \\
\text { Producers can choose between the minimum } \\
\text { guaranteed tariff (prezzo minimo garantito) set } \\
\text { by the energy authority and market prices at } \\
\text { ritirodedicato. }\end{array}$ \\
\hline $\begin{array}{l}\text { Ministerial } \\
\text { decree of July 7, } \\
2012\end{array}$ & $\begin{array}{l}\text { Premium tariff I (Conto Energia V) EUR } \\
0.133-0.274 / \mathrm{kWh}\end{array}$ & $\begin{array}{l}\text { The tariff is valid until the estimated total } \\
\text { annual cost of incentives reaches EUR 6.7 } \\
\text { billion for photovoltaic operators and cannot } \\
\text { use the basic «green» tariff }\end{array}$ \\
\hline
\end{tabular}

Source: own study based on (GSE 2014).

In Italy, in 1999, a division of the National Transmission System Operator (GRTN) was established by order of Bersani to move to the liberalization of the electricity sector. Since 2005, it has changed its name to GSE and becomes a state-owned energy company, which performs special responsibilities in the energy sector in accordance with the strategic and operational 
guidelines of the state and is accountable to the Ministry of Economy and Finance (Gestore Rete Trasmissione Nazionale 2002). This state structure organizes, manages and provides incentives for the production of electricity from renewable sources, as well as issues "green" certificates. There is a system of quotas, for which incentives were provided for exceeding in 2012 (quota for the first half of $730 \mathrm{MW}$, and for the second $-720 \mathrm{MW}$ ).

In addition to such organizational measures, the government provides preferential taxation on real estate for buildings equipped with renewable energy. The amount of such taxation depends on the value of the property and varies by municipality.

The Italian government has adopted an Integrated Energy and Climate Plan until 2030 (Ministry of Economic Development of Italy 2018), which provides for implementation in 5 areas: decarbonization, energy efficiency, energy security, the internal energy market, research, innovation and competitiveness (Labunska et al. 2017; Pukala and Petrova 2019; Koval at al. 2019).

TABLE 2. Energy growth targets [MW] from renewable sources by 2030 in Italy

TABELA 2. Cele wzrostu mocy zainstalowanej [MW] ze źródeł odnawialnych do 2030 r. we Włoszech

\begin{tabular}{|l|r|r|r|r|}
\hline \multicolumn{1}{|c|}{ Energy sources } & 2016 & 2017 & 2025 & 2030 \\
\hline Hydropower & 18,641 & 18,863 & 19,140 & 19,200 \\
\hline Geothermal energy & 0,815 & 0,813 & 0,919 & 0,950 \\
\hline Wind energy & 9,410 & 9,766 & 15,690 & 18,400 \\
\hline Bioenergy & 4,124 & 4,135 & 3,570 & 3,764 \\
\hline Solar energy & 19,269 & 19,682 & 26,840 & 50,880 \\
\hline Total & 52,258 & 53,259 & 66,159 & 93,194 \\
\hline
\end{tabular}

Source: own study based on (Ministry of Economic Development of Italy 2018).

TABLE 3. Targets and trajectories of growth of the share of renewable sources in the electricity sector [TWh] by 2030 in Italy

TABELA 3. Cele i trajektorie wzrostu udziału OZE w sektorze elektroenergetycznym [TWh] do $2030 \mathrm{r}$. we Włoszech

\begin{tabular}{|l|r|r|r|r|}
\hline \multicolumn{1}{|c|}{ Energy sources } & \multicolumn{1}{c|}{2016} & \multicolumn{1}{c|}{2017} & \multicolumn{1}{c|}{2025} & \multicolumn{1}{c|}{2030} \\
\hline Hydropower & 46.2 & 46.0 & 49.0 & 49.3 \\
\hline Wind energy & 16.5 & 17.2 & 31.0 & 40.1 \\
\hline Geothermal energy & 6.3 & 6.2 & 6.9 & 7.1 \\
\hline Bioenergy & 19.4 & 19.3 & 16.0 & 15.7 \\
\hline Solar energy & 22.1 & 24.4 & 36.4 & 74.5 \\
\hline Gross domestic electricity consumption & 325.0 & 331.8 & 331.8 & 337.3 \\
\hline The share of renewable energy [\%] & 34.0 & 34.1 & 42.0 & 55.4 \\
\hline
\end{tabular}

Source: own study based on (Ministry of Economic Development of Italy 2018). 
Accordingly, such support should ensure the priority development of solar energy by 2030 , which will reach $50 \mathrm{GW}$ of photovoltaics plus $0.88 \mathrm{GW}$ of solar thermal energy, as well as the production of $74.5 \mathrm{TWh} ; 40 \%$ of which is RES and will account for $22 \%$ of its share in electricity).

TABLE 4. Targets of RES for electricity in Italy for the period 2020-2040

TABela 4. Cele OZE dla energii elektrycznej we Włoszech na lata 2020-2040

\begin{tabular}{|l|r|r|r|r|}
\hline \multicolumn{1}{|c|}{ Energy sources } & 2020 & 2025 & 2030 & 2040 \\
\hline Renewable energy sources & 118.1 & 120.5 & 132.0 & 142.9 \\
\hline Hydropower & 49.6 & 49.1 & 51.0 & 51.6 \\
\hline Wind energy & 19.6 & 21.8 & 25.1 & 33.2 \\
\hline Geothermal energy & 6.7 & 6.9 & 7.0 & 8.3 \\
\hline Bioenergy & 15.9 & 14.7 & 14.2 & 12.3 \\
\hline Solar energy & 26.3 & 28.0 & 34.6 & 37.7 \\
\hline Gross domestic electricity consumption & 329.7 & 333.1 & 340.6 & 351.7 \\
\hline The share of renewable energy [\%] & 35.8 & 36.2 & 38.7 & 40.6 \\
\hline
\end{tabular}

Source: own study based on (Ministry of Economic Development of Italy 2018).

\subsection{Regulatory policy of renewable energy sources in the US}

There is no single system of state support for renewable generation in the United States. However, regulatory support for renewable energy is provided at the national and regional levels.

Regional support is more dynamic and intensive (Fig. 1).

Therefore, since 2000, 50\% of renewable energy in the United States has been developed through regional support. Relatively strong financial support is also received at the national level (Table 6). However, this support is declining every year. The main toolss to support renewable energy in the United States are financial and investment.

The US Department of Energy's loan program has supported many successful projects, including 18 existing power plants (11 solar, 4 wind and 3 geothermal). 
TABLE 5. State regulation of renewable energy tariffs in the United States

TABELA 5. Stanowa regulacja taryf energii odnawialnej w Stanach Zjednoczonych

\begin{tabular}{|c|l|l|}
\hline Year & \multicolumn{1}{|c|}{ Law } & \multicolumn{1}{c|}{ Characteristic } \\
\hline 1978 & $\begin{array}{l}\text { Law (PURPA) "On Regulatory } \\
\text { Policy in the Field of Public } \\
\text { Utilities" }\end{array}$ & $\begin{array}{l}\text { Tax incentives for the production of electricity from renewable } \\
\text { sources and opened access to independent producers of «green» } \\
\text { electricity to the grid. }\end{array}$ \\
\hline 2092 & Law "On Energy" & $\begin{array}{l}\text { Liberalized the electricity market and allowed to provide tax } \\
\text { benefits to producers of electricity from renewable sources in order } \\
\text { to commercialize them. }\end{array}$ \\
\hline 2007 & $\begin{array}{l}\text { Law “On Energy Policy" } \\
\text { (EPAct 2005) }\end{array}$ & $\begin{array}{l}\text { The mechanism of providing credit guarantees for the development } \\
\text { of innovative technologies in RES. }\end{array}$ \\
\hline (EISA 2007) & $\begin{array}{l}\text { Designing ordinary buildings from 2020, without a 100\% guarantee } \\
\text { of energy independence is not allowed. }\end{array}$ \\
\hline
\end{tabular}

Source: own study based on (IRENA 2015).

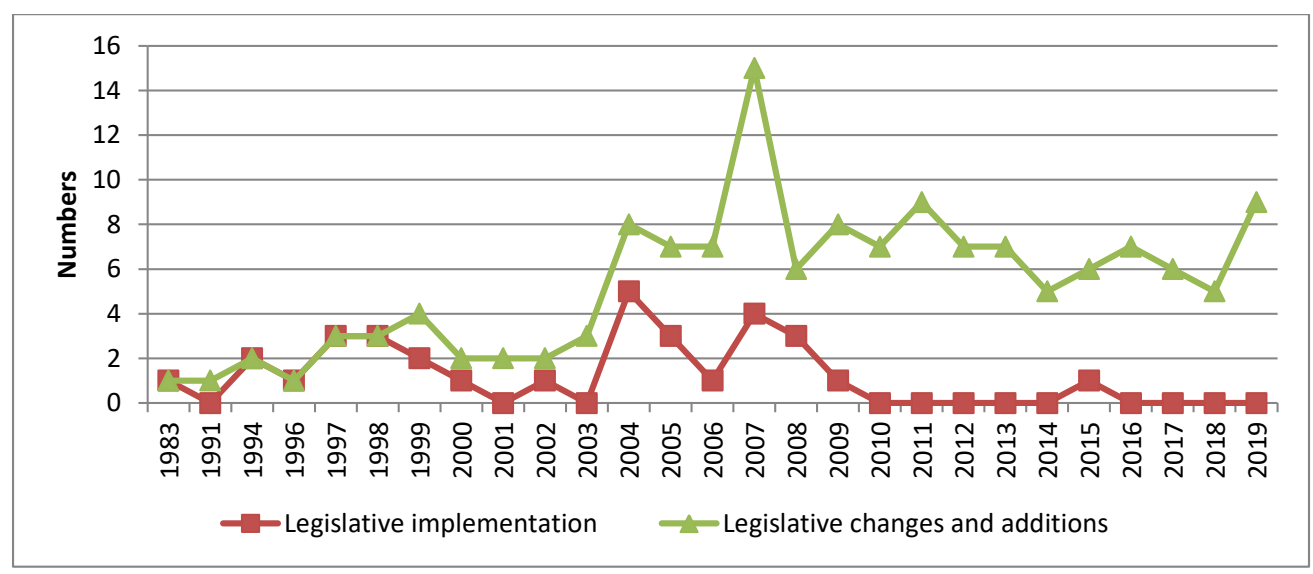

Fig. 1. Introduction of regional RPS and changes to them in the states of the US in the period from 1983 to 2019 Source: own study based on (Piper et al. 2019)

Rys. 1. Wprowadzenie regionalnych RPS i ich zmiany w USA w okresie od 1983 do 2019 r.

\subsection{Mechanisms of state regulation of development renewable energy in Poland}

Since 2008, the "green" tariff has been introduced in Poland. And in 2017, Poland switched from a "green" tariff to a system of allowances (feed-in premium) (Kohler 2021). This system assumes that producers receive an additional generation fee when selling electricity on the mar- 
TABLE 6. Financial support for US renewable energy

TABELA 6. Wsparcie finansowe dla energii odnawialnej w USA

\begin{tabular}{|l|l|}
\hline \multicolumn{1}{|c|}{ RES support tools } & \multicolumn{1}{c|}{ Characteristic } \\
\hline $\begin{array}{l}\text { Investment Tax Credit } \\
\text { (ITC) }\end{array}$ & $\begin{array}{l}\text { Investment subsidy for the implementation of renewable energy projects that is } \\
\text { expected to be produced in the future. The subsidy is received after the facility is put } \\
\text { into operation. The unused amount may be carried forward. }\end{array}$ \\
\hline $\begin{array}{l}\text { Production Tax Credit } \\
\text { (PTC) }\end{array}$ & $\begin{array}{l}\text { A tax credit is provided for the produced electricity in the amount of a fixed amount per } \\
\text { unit of output. PTC is paid only when the target product is delivered (in this case solar } \\
\text { energy). This type of subsidy is provided for a certain period. } \\
\text { These incentives are decreasing every year and should eventually cease to have effect. }\end{array}$ \\
\hline Direct credit & $\begin{array}{l}\text { The interest on the loan is slightly higher than the US Treasury rates, but the guarantor } \\
\text { of the loan is the Ministry. }\end{array}$ \\
\hline Partial loan guarantees & The amount of the guarantee is limited to $80 \%$ of the project cost. \\
\hline
\end{tabular}

Source: own study based on (Barbose 2021).

ket. The surcharge can be fixed or defined as the difference between the market price and the "green" tariff for a particular type of generation. Due to the large number of solar power plants (the total capacity of solar energy exceeded $4.5 \mathrm{GWp}$ ) here is a situation where medium power grids cannot provide electricity from solar generation, so large Polish networks (Innogy Stoen, Tauron Dystrybucja, Enea, Energa and PGE) have a connection of solar power plants (64 solar power plants were refused in 2018, and 437 in 2019) (Rogalski 2018).

These small stations receive income from the "Mój Prąd" funding program and support the active development of household solar stations (Olczak et al. 2021a; Olczak et al. 2020; Cader et al. 2021). The refusal to connect the stations covers the state subsidy of this solar generation. Thus, since 2017, the country has not had a "green tariff" as an economic tool for regulating and stimulating alternative energy. Simply, the Polish government sets a higher price than from other sources. But at these tariffs, producers can sell a limited amount of energy - everything above the limit is sold at market prices (Olczak et al. 2021b).

Legislative changes in 2019 regarding alternative energy ensured the country's entry into the leading positions and formed competition among investors in solar generation. If by 2019 the share of alternative energy was up to $3 \%$ of the total, then in 9 months Poland would begin to generate gigs of solar energy.

\subsection{Current trends in the development of renewable energy in China}

China has been a leader in the development of alternative energy since 2018. In 8 years it managed to increase the amount of generating capacity three fold (REN21 2018). In 2005, the Chinese Communist Party passed the Renewable Energy Act (MOFCOM 2013). Accordingly, 
the five-year plans for specific goals and regulating the relations between the participants in the development of the industry were implemented (Shmygol et al. 2020; Tsimoshynska et al. 2021). Other regulations have formed the foundation for the development of RES.

Therefore, according to the goals of the 13-year plan (2016-2020), the share of RES in consumption by 2020 should be $15 \%$ (Climate Change Laws of the World 2016). But according to the National Energy Administration, in the first half of 2020, China's RES is experiencing a rapid increase in the capacity of this energy sector. Wind power increased by $10.9 \%$; (compared to the same period in 2019), and the capacity of Solar Energy Systems (SES) increased by $20 \%$.

In 6 months of 2020, the newly introduced wind power generated 6.32 million $\mathrm{kW}$ and solar 11.52 million $\mathrm{kW}$, which allowed the country to secure a share of $27 \%$ and enter the world championship in RES production in 2019 (National Energy Administration 2021).

In addition, the implementation of the global strategy "One Belt, One Road" encourages Chinese RES producers to actively export such energy technologies and implement large projects in other countries (National Development and Reform Comission 2019).

The economic basis for such development was the formation of the Renewable Energy Development Fund to subsidize wind and solar power plants. It allows the difference between the tariffs for the supply of "green" energy and the provincial tariffs for coal energy to be covered. However, at the end of 2017, the fund's deficit reached CNY 100 billion, and manufacturers say they have not received money since 2015 .

The first basis for regulating all of Britain's energy has been the government's policy of liberalizing the national energy market since the late 1980 s, when a law was passed that allowed private generating companies to operate and guaranteed free electricity. Subsequently, the adoption of the White Paper on the Privatization of Electricity allowed small producers to operate, and the 2000 law changed pricing in the energy market and bilateral agreements came into force. In fact, the principle of free conclusion of contractual relations of market participants for electricity and related services came into force on the market.

Subsequent energy laws of 2004, 2008, 2010, 2013, 2016 (Energy Act 2004, 2008, 2010, 2013, 2016) and the Climate Change Act of 2008 (Climate Change Act 2008) allowed for the implementation of energy market liberalization policies and increased competition, which provides more efficient use of available material and financial resources.

The Fukushima incident, which was recognized as synonymous with the nuclear threat of all mankind, reoriented the priorities of energy development from traditional to alternative. In general, such reforms and global trends in nuclear energy have ensured that large foreign companies and investors identify the UK energy market as the most attractive and invest in new production facilities and research programs.

Since 2007, the government has prioritized offshore areas for wind farms with an additional capacity of $25 \mathrm{GW}$. Accordingly, such liberal regulation has made it possible for the UK to have five small wind companies, leading the top ten in the world, located in the country and providing an annual income of GBP 750 million. And the capacity of wind farms by 2040 , the total capacity can reach $9 \mathrm{GW}$. 


\subsection{State regulation of renewable energy sources in the UK}

In the UK, there were two RES support schemes: fixed tariffs (FIT) for systems up to $5 \mathrm{MW}$ of installed capacity and quota (Renewable Obligation - RO or ROC). However, these schemes have been replaced by a new mechanism - "Contracts for Difference - CfD", and apply to facilities from $5 \mathrm{MW}$ of electricity generation.

Further regulation of the energy market envisages a 20\% increase in VAT for Solar Energy Systems (the preferential amount was only 5\%). In addition, it is planned to change the payment by households for the use of electricity networks - the establishment of a single fee of 64 pounds per year instead of payment per unit of electricity consumed.

\subsection{Efficiency of state regulation based on mathematical and economic model}

This review notes the priority of the factor of state regulation of renewable energy. We will calculate the impact of the level of state regulation on trends in the development of renewable generations.

The development of renewable energy reflects a certain dynamic. At first there were isolated RES installations, and later their number and capacity increased. Accordingly, their number and intensity directly depends on the government's regulatory policy. Therefore, the dynamics of its development depends on a number of factors. But all of them can be reduced to two interdependent groups. The first group is tax regulation, namely the creation of conditions for the development and expansion of solar energy. The second factor is the money sums that are directed to their development.

These two factors allow us to form the equation $(x, y)=f 1(x) f 2(y)$, which simply translates into a differential form $d y / d x=f 1(x) f 2(y)$. In economic terms, these two variables cannot have a value of zero. Therefore, mathematically, the differentials of the function of the argument $\mathrm{x}$ in both parts of the equation determine the maintenance of the constant by which they differ.

At time $t=0$, a number of renewable energy stations $(N)$ are already in force and, accordingly, the current tax legislation (which may not stimulate the development of renewable energy). In the next moment of time $t>0$ with the introduction of government incentives, changes and the amount of investment (or financing of a solar power plant), their number will be $-x(t)$. Therefore, we have a differential equation:

$$
\frac{d y}{d t}=k x(N-x)
$$


where:

$k$ - a positive proportionality factor, which depends solely on the effectiveness of government policy. From the equation we obtain the equality of the differentials of the two functions of the argument $t$ :

$$
\frac{d x}{x(N-x)}=k d t
$$

Integrating the left and right parts, we find a common solution:

$$
\frac{1}{N} \ln \frac{x}{N-x}=k t+C
$$

The general solution includes an indefinite constant $C$. Assuming $N C=D$, we obtain the equality:

$$
\frac{x}{N-x}=e^{N k t+D}
$$

from which we define the function $x(t)$ :

$$
x=\frac{N}{1+E_{e}^{-N k t}}
$$

In this case $E=e-D$. In fact, we go to the logistic function, and its graph is a logical curve.

If we consider that $x(0)=x 0 ; x 0=N / \alpha$, where $\alpha>0$ (lag manifestation of government policy), then it will be possible to find the value of the constant $E$.

The logistics function will take the form:

$$
x=\frac{N}{1+(\alpha-1) e^{-N k t}}
$$

If we take the value of $N$ conditionally for 1 , and the value of $k$ is taken as 0.5 , the calculation $\alpha$ indicates dependences, as shown in the Figure 2.

Figure 2 shows the lag of government policy. If $\alpha=100$, it means that government policy is nominal but ineffective. It outlines measures for renewable energy sources, but does not really control them. If $\alpha=1.3$, this means the effective regulation of external challenges of public policy regarding renewable energy sources.

Thus, in the field of renewable energy there will be a saturation of solar power plants, and in addition, this energy is not able to completely replace the traditional one. However, the saturation of solar power plants is possible only through government regulation. That is why there is a transition of the green tariff to its various incentives. 


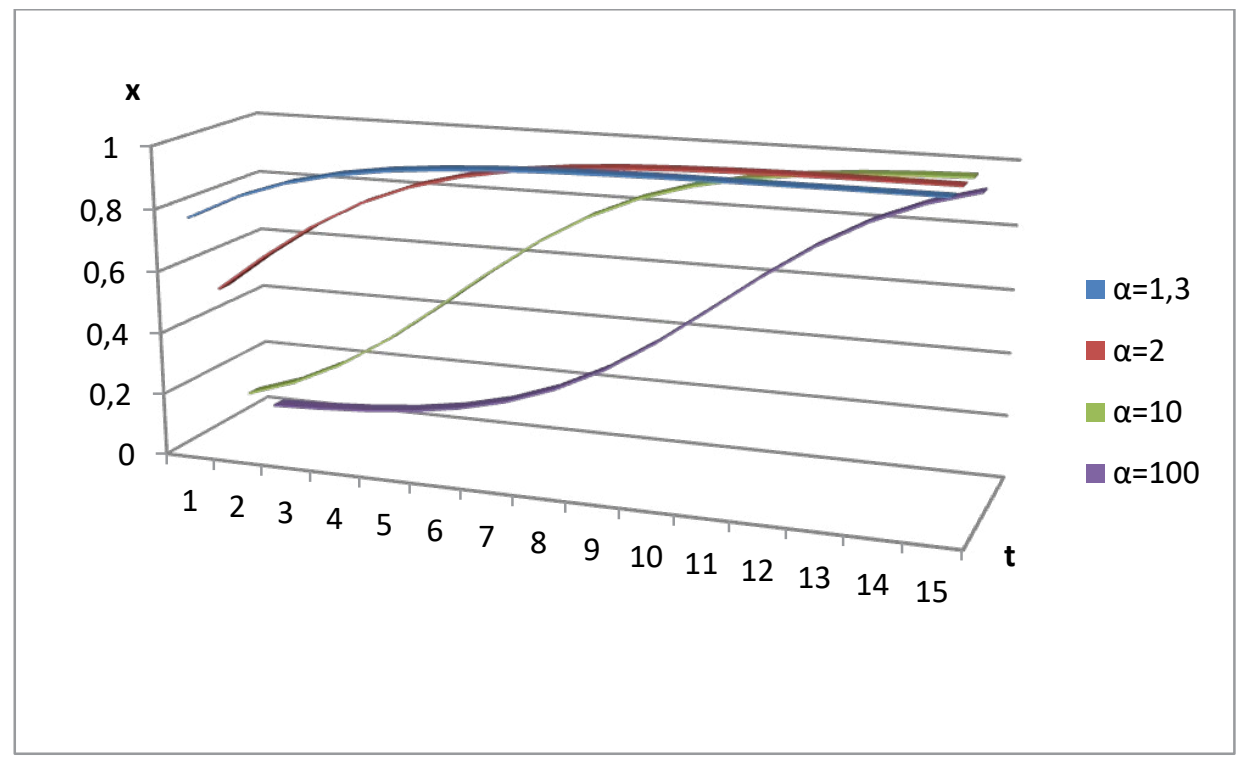

Fig. 2. Abstract model of manifestation of efficiency of government regulation in time per conditional unit of renewable energy stations

Rys. 2. Abstrakcyjny model skuteczności regulacji rządowych na jednostkową instalację OZE (w czasie)

\section{Conclusions}

Unequivocally, the development of renewable energy has taken place thanks to active state support. Such support has been actively implemented since 1990 in developed countries and its level of influence varies from country to country. It should not be ruled out that the development of renewable energy depended on a historic event, the Chernobyl incident, and later the incident at the Fukushima nuclear power plant. These two obvious cases became the starting point for the allocation of alternative energy to the independent sector.

The practical impulse for the progressive replacement of existing traditional energy by renewable energy sources was signed by the governments of the Paris Agreement on supporting the reduction of decarbonization in industry. Therefore, the governments of the countries that have recognized these requirements began to develop national strategies, which were determined by the main ones, and renewable energy received the status of a priority development and was formed as a full-fledged sector of modern energy.

The greatest result of liberal regulation of the energy market was provided by Great Britain. This approach has made it possible to take the initiative in the market and small energy companies and to attract private investment. State regulation was carried out carefully and allowed to 
move mainly to the wholesale sale of electricity, which provides for the introduction of payment for its use for households as wholesale.

The Chinese Communist Party has demonstrated the effectiveness of long-term phased management of renewable energy development. With such a large-scale reform of the government, it was possible to bring the countries to the world's leading positions. In the economic approach, the success of such transformations is due to the mechanism of subsidizing this new energy sector. However, the deficit of this subsidy was the main reason for the slowdown in the development of "green" energy in 2019.

The "green" tariff has become a separate universal tool for stimulating and activating the development of renewable energy. This tariff has become an economic mechanism for rewarding the generation of electricity from renewable energy sources. Its magnitude varies over time and the geography of countries.

But it offset the cost of installing the equipment, further encouraging new power generation after the equipment paid off, and ultimately ensuring a mass transition to renewable energy. In this period, this economic instrument in terms of payments and compensation for energy development has almost exhausted itself.

This situation is due to purely objective technological changes (technology has developed significantly and led to lower prices for equipment and components). In addition, its further application leads to a redistribution of household funds to the accounts of renewable energy companies, which automatically increases the cost of all electricity. As a result, most governments are gradually reducing its role in the economic regulation of national energy so as not to encourage the widespread use of shadow funds and the use of a lobbying mechanism in the adoption of new legal norms.

Thus, the study indicates that renewable energy has come a long way when it needed attention and government encouragement and is at a stage of sustainable development, which already depends on the general economic situation. A solution to the problem of regulating electricity flows in combination with traditional energy infrastructure is in the future.

\section{References}

Barbose, G.L. 2021. US Renewables Portfolio Standards 2021 Status Update: Early Release. Berkeley, United States: Lawrence Berkeley National Laboratory (LBNL).

Bazaluk et al. 2021a - Bazaluk, O., Havrysh, V. and Nitsenko, V. 2021a. Energy and environmental assessment of straw production for power generation. E3S Web of Conferences 228, DOI: 10.1051/ e3sconf/202122801010.

Bazaluk et al. 2021b - Bazaluk, O., Havrysh, V., Fedorchuk, M. and Nitsenko, V. 2021b. Energy Assessment of Sorghum Cultivation in Southern Ukraine. Agriculture 11(8), DOI: 10.3390/agriculture11080695.

BMWi 2010. Bundesministerium für Wirtschaft und Technologie (BMWi) 2010. Energiekonzept für eine umweltschonende, zuverlässige und bezahlbare Energieversorgung. Berlin: Bundesministerium für Wirtschaft und Technologie. 
CAder et al. 2021 - CAder, J., Olczak, P. and Koneczna, R. 2021. Regional dependencies of interest in the "My Electricity" photovoltaic subsidy program in Poland. Polityka Energetyczna - Energy Policy Journal 24(2), pp. 97-116, DOI: 10.33223/epj/133473.

Climate Change Act 2008. [Online] https:/www.legislation.gov.uk/ukpga/2008/27/contents [Accessed: 2021-09-05].

Climate Change Laws of the World 2016. $13^{\text {th }}$ Five-Year Plan. [Online] https://www.climate-laws.org/ geographies/china/policies/13th-five-year-plan [Accessed: 2021-09-05].

Edie Newsroom 1999. GERMANY: Shell opens solar cell factory in Europe's 'Solar Valley'. [Online] https://www.edie.net/news/0/GERMANY-Shell-opens-solar-cell-factory-in-Europes-Solar-Valley/1977 [Accessed: 2021-09-05].

EISA 2007. Energy Independence and Security Act of 2007. [Online] https://www.govinfo.gov/content/ pkg/BILLS-110hr6enr/pdf/BILLS-110hr6enr.pdf [Accessed: 2021-09-05].

Energy Act 2004. UK Public General Acts. [Online] https://www.legislation.gov.uk/ukpga/2004/20/contents [Accessed: 2021-09-05].

Energy Act 2008. UK Public General Acts. [Online] https://www.legislation.gov.uk/ukpga/2008/32/contents [Accessed: 2021-09-05].

Energy Act 2010. [Online] https://www.legislation.gov.uk/ukpga/2010/27/pdfs/ukpga_20100027_en.pdf [Accessed: 2021-09-05].

Energy Act 2013. [Online] https://www.legislation.gov.uk/ukpga/2013/32/pdfs/ukpga_20130032_en.pdf [Accessed: 2021-09-05].

Energy Act 2016. UK Public General Acts. [Online] https://www.legislation.gov.uk/ukpga/2016/20/contents/enacted [Accessed: 2021-09-05].

EPAct 2005. Energy Policy Act of 2005, Public Law 109-58. [Online] https://www.congress.gov/109/ plaws/publ58/PLAW-109publ58.pdf [Accessed: 2021-09-05].

Erneuerbare-Energien-Gesetz 2000. [Online] https://www.clearingstelle-eeg-kwkg.de/eeg2000 [Accessed: 2021-09-05].

Erneuerbare-Energien-Gesetz 2004. [Online] https://www.clearingstelle-eeg-kwkg.de/eeg2004 [Accessed: 2021-09-05].

Erneuerbare-Energien-Gesetz 2009. [Online] https://www.clearingstelle-eeg-kwkg.de/eeg2009 [Accessed: 2021-09-05].

Erneuerbare-Energien-Gesetz 2014. Retrieved from https://www.clearingstelle-eeg-kwkg.de/eeg2014 [Accessed: 2021-09-05].

Gestore Rete Trasmissione Nazionale 2002. Provisional Data on Operation of the Italian Power System. [Online] http://collaudo.download.terna.it/terna/0000/0124/06.PDF [Accessed: 2021-09-05].

GSE 2014. Incentivazionedellaproduzione di energiaelettrica da impianti a fontirinnovabilidiversidai fotovoltaici. [Online] https://www.gse.it [Accessed: 2021-09-05].

GSE 2021. Energy consumption. [Online] https://www.gse.it/ [Accessed: 2021-09-05].

IRENA 2015. Renewable Energy Prospects: United States of America. [Online] https://www.irena.org/publications/2015/Jan/Renewable-Energy-Prospects-United-States-of-America [Accessed: 2021-09-05].

IRENA 2020. Country Rankings. [Online] https://www.irena.org/Statistics/View-Data-by-Topic/Capacity -and-Generation/Country-Rankings [Accessed: 2021-09-05].

Kholiavko et al. 2020 - Kholiavko, N., Popova, L., Marych, M., Hanzhurenko, I., Koliadenko, S. and Nitsenko, V. 2020. Comprehensive methodological approach to estimating the research component influence on the information economy development. Naukovyi Visnyk Natsionalnoho Hirnychoho Universytetu 4(178), pp. 192-199, DOI: 10.33271/nvngu/2020-4/192.

KoHLER, T. 2021. Renewable Energies marketing models Poland. [Online] https://www.roedl.com/renewable-energy-consulting/markets/countries/marketing-models-poland [Accessed: 2021-09-05]. 
Koval et al. 2021 - Koval, V., Hrymalyuk, A., Kulish, A., Kontseva, V., Boiko, N. and Nesenenko, P. 2021. Economic policy of industrial development and investment approach to the analysis of the national economy. Estudios De Economia Aplicada 39(6), DOI: 10.25115/eea.v39i6.5263.

Koval et al. 2019 - Koval, V., SRibna, Y. and Gaska, K. 2019. Energy cooperation Ukraine-Poland to strengthen energy security. E3S Web Conference 132, 01009, DOI: 10.1051/e3sconf/201913201009.

Labunska et al. 2017 - Labunska, Sv., Petrova, M. and Prokopishyna, O. 2017. Asset and cost management for innovation activity. Economic Annals - XXI 165(5-6), pp. 13-18, DOI: 10.21003/ea.V165-03.

Ministry of Economic Development of Italy 2018. Proposta di piano nazionaleintegrato per l'energia e il clima. [Online] https://www.mise.gov.it/images/stories/documenti/Proposta_di_Piano_Nazionale_Integrato_per_Energia_e_il_Clima_Italiano.pdf [Accessed: 2021-09-05] (in Italian).

MOFCOM 2013. Renewable Energy Law of the People's Republic of China. [Online] http://english.mofcom.gov.cn/article/policyrelease/Businessregulations/201312/20131200432160.shtml [Accessed: 2021-09-05].

National Development and Reform Comission 2019. [Online] https://web.archive.org/web/20190511191431/ http://www.ndrc.gov.cn/gzdt/201509/t20150921_751695.html [Accessed: 2021-09-05].

National Energy Administration 2021. [Online] http://english.www.gov.cn/state_council/2014/10/01/content_281474991089761.htm [Accessed: 2021-09-05].

Olczak at al. 2020 - Olczak, P., Matuszewska, D. and Kryzia, D. 2020. "Mój Prąd" as an example of the photovoltaic one off grant program in Poland. Polityka Energetyczna - Energy Policy Journal 23(2), pp. 123-138, DOI: $10.33223 /$ epj/122482.

OlczaK at al. 2021a - OlczaK, P., Kryzia, D., Matuszewska, D. and Kuta, M. 2021a. "My Electricity" Program Effectiveness Supporting the Development of PV Installation in Poland. Energies 14(1), 231, DOI: $10.3390 / \mathrm{en} 14010231$.

Olczak et al. 2021b - Olczak, P., Przemyslaw, J., Kryzia, D., Matuszewska, D., FyK, M. and Dyczko, A. 2021b. Analyses of duck curve phenomena potential in polish PV prosumer households' installations. Energy Reports 7, November 2021, pp. 4609-4622, DOI: 10.1016/j.egyr.2021.07.038.

Piper et al. 2019 - Piper, S., Cotting, A., Wilson, A., O’Reilly, J., Hlinka, M., Lehmann, J. and Hering, G. 2019. The 2020 US renewable energy outlook. [Online] https://www.spglobal.com/marketintelligence/en/news-insights/research/the-2020-us-renewable-energy-outlook [Accessed: 2021-09-05].

Pukala, R. and Petrova, M. 2019. Application of the AHP method to select an optimal source of financing innovation in the mining sector. E3S Web of Conferences 105, DOI: 10.1051/ e3sconf $/ 201910504034$.

REN21 2018. A comprehensive annual overview of the state of renewable energy. [Online] https://www. ren21.net/wp-content/uploads/2019/08/Full-Report-2018.pdf [Accessed: 2021-09-05].

Shmygol et al. 2020 - Shmygol, N., Schiavone, F., Trokhymets, O., Pawliszczy, D., Koval, V., ZavGORODNiY, R. and Vorfolomeiev, A. 2020. Model for assessing and implementing resource-efficient strategy of industry. CEUR Workshop Proceedings 2713, pp. 277-294.

Rogalski, T. 2018. A guide to support for Polish renewable energy sources following the 2018 amendments. [Online] https://www.nortonrosefulbright.com/de-de/wissen/publications/5932a770/a-guide-to-support -for-polish-renewable-energy-sources-following-the-2018-amendments [Accessed: 2021-09-05].

Tsimoshynska et al. 2021 - Tsimoshynska, O., Koval, M., Kryshtal, H., Filipishyna, L., Arsawan, W.E. and KovaL, V. 2021. Investing in road construction infrastructure projects under public-private partnership in the form of concession. Naukovyi Visnyk Natsionalnoho Hirnychoho Universytetu 2, pp. 184-192, DOI: 10.33271/nvngu/2021-2/184.

Yankovyi et al. 2021 - Yankovyi, O., Koval, V., Lazorenko, L., Poberezhets, O., Novikova, M. and Gonchar, V. 2021. Modeling Sustainable Economic Development Using Production Functions. Estudios de Economia Aplicada 39(5), DOI: 10.25115/eea.v39i5.5090. 


\section{Viktor Koval, Yevheniia Sribna, Sylwester Kaczmarzewski, Alla Shapovalova, Viktor STUPNYTSKYI \\ Polityka regulacyjna państw europejskich w zakresie odnawialnych źródeł energii}

\section{Streszczenie}

W artykule dokonano analizy i oceny rozwoju energetyki odnawialnej z punktu widzenia regulacji i dotacji w różnych państwach. Warto zauważyć, że światowa produkcja energii elektrycznej ze źródeł odnawialnych odnotowała wzrost o $15 \% \mathrm{w}$ ciągu ostatniego roku. W niniejszym artykule analizie poddano okresy wprowadzania „green tariff” jako ekonomicznego bodźca do rozwoju energetyki słonecznej, które stały się punktem wyjścia do rozwoju alternatywnych źródeł energii w różnych krajach. Czynniki instytucjonalne w rozwoju OZE mogą obejmować działania takie jak bezpłatne wydawanie koncesji na wytwarzanie energii elektrycznej, stymulowanie tworzenia specjalistycznych obszarów badawczych, rozwój technologii i produkcja odpowiednich urządzeń. W artykule wykazano konieczność uwzględniania specyfiki danego regionu $\mathrm{w}$ organizowanym przez państwo stymulowanym rozwoju energetyki odnawialnej. Efektywność ekonomiczną wprowadzanych przez państwo działań dla rozwoju OZE obliczono w przeliczeniu na jednostkę instalacji OZE z uwzględnieniem współczynnika proporcjonalności. $Z$ tego względu wyniki wskazują na wysoką skuteczność polityki rządu w obszarze regulacji jedynie w zakresie krótkotrwałego opóźnienia $(\alpha=1,3)$ oraz liczby instalacji w wysokości maksymalnej $80 \%$ pełnego nasycenia w stosunku do standardowego zapotrzebowania na energię. Zidentyfikowano dalsze etapy rozwoju energetyki odnawialnej bez wprowadzania i rozszerzania ,green tariff”. Takie podejście zostało wprowadzone w Polsce, co zapewniło krajowi nie tylko napływ inwestycji zagranicznych, ale także powstanie wolnej konkurencji wśród inwestorów.

SŁOWA KLUCZOWE: energia odnawialna, „zielona” taryfa, preferencyjne opodatkowanie, państwowe regulacje energii odnawialnej, elektrownie słoneczne 
